\title{
Monitoring of masonry historical constructions: ten years of static monitoring of the world's largest oval dome.
}

\author{
Rosario Ceravolo ${ }^{1}$, Marica L. Pecorelli ${ }^{2}$, \\ Luca Zanotti Fragonara ${ }^{3}$, Annunziata De Marinis ${ }^{4}$ \\ ${ }^{1,2,4}$ Politecnico di Torino, Department of Structural, Building and Geotechnical Engineering, \\ Corso Duca degli Abruzzi, 24 -10129 Turin, Italy \\ ${ }^{3}$ Cranfield University, School of Aerospace, Transportation and Manufacturing, \\ College Road, Cranfield, MK43 OAL, United Kingdom
}

\begin{abstract}
This paper presents the analyses conducted on data acquired by the monitoring system of the "Regina Montis Regalis" Basilica of Vicoforte in the decade 2004-2014. The Basilica is a building of great historical, architectural and structural significance, owing its fame to its impressive masonry oval dome, the world's largest of this shape (internal axes of 37.23 by $24.89 \mathrm{~m}$ ).

The dome-drum system of the Basilica has suffered over the years of significant structural problems, partly due to settlements of the building induced progressively by newly built masses and partly due to the sliding of the underground. In 1983, concerns over the severe settlements and cracking phenomena affecting the structure prompted the decision to undertake strengthening interventions. A special hooping system, consisting of 56 tie-bars, placed around the oval perimeter of the dome, was thus conceived to limit the crack opening.

The monitoring system of the Basilica installed in the early 1980s underwent several upgrading and in 2004 its acquisition procedure was automatized. A total number of 112 instruments, consisting of temperature sensors, crackmeters, load cells, pressure cells, wire gauges, hygrometer, piezometers and hydrometer, are currently installed on the Basilica.

This study is primarily focused on data acquired by the crackmeters, the extensometers along the main axes of dome and the load cells placed at the ends of the tie-bars. The main aim of the

\footnotetext{
${ }^{4}$ Dott. Ing., annunziata.demarinis@studenti.polito.it
}

${ }^{1}$ Professor*, rosario.ceravolo@polito.it

${ }^{2}$ Research Fellow, marica.pecorelli@polito.it

${ }^{3}$ Research Fellow, l.zanottifragonara@cranfield.ac.uk
\end{abstract}


reported analyses is to evaluate the behaviour of the web cracks on the Basilica and the structural performance of the strengthening interventions put in place in 1985-1987.

Keywords: Regina Montis Regalis Basilica, structural health monitoring, static monitoring, long-term monitoring, oval dome, cultural heritage.

\section{INTRODUCTION}

Historical structures are subjected to ageing effects and require expensive maintenance and surveillance against accidental events in order to preserve them. A monitoring system has the purpose of recording the variations of some significant parameters such as crack openings, tilting, deformations, thermal variations, etc [1] [2]. Monitoring systems are used in different situations, among which: (i) recording of evolving phenomena such as soil settlements; (ii) checks on the efficacy of structural interventions and safety measures; (iii) control of the behaviour of the structures when there are works in progress and (iv) as an alternative to interventions, limiting the actions on this monumental structure. Specialised sensors are put in place to monitor the evolution of different structural phenomena (crack opening, deformations, stress, etc.) and environmental conditions (temperature, external load, etc). Knowledge of the environmental conditions plays a fundamental role in order to identify and understand the actual evolution of structural phenomena. The data acquired from monitoring systems will be inevitably affected by the environmental conditions and many other factors, whose effect on trends is removed recurring to data cleansing and processing tools.

Generally, long-term monitoring data can improve the accuracy of numerical model of ancient masonry structures, characterised by many uncertainties. Corroborated models can predict the response of buildings to future loads (such as seismic actions) and the efficacy of strengthening interventions.

In order put this study in a more general context, it is worth recalling a few examples of static monitoring systems installed on some important domes [3] [4] [5] [6] [7] [8] [9]. The case of S. Marco Cathedral in Venice is an example of long-term monitoring system. Installed in 1991 after diagnostic interventions, it has provided interesting results, also due to the methodological approach used to analyse the acquired data, allowing a separation of the strains induced by thermal effects 
from those related to other phenomena [7]. Data from structural monitoring of historical buildings can be also used to confirm and corroborate previous analytical or numerical studies: this is the prominent case of the Santa Maria del Fiore's dome in Florence [3] [4] [5] [6]. The dome presents an ancient and widespread crack pattern extensively analysed in the literature. Three main hypotheses have been suggested about the damage suffered by the dome: (i) the excessive weight of the dome; (ii) differential settlement phenomena at the foundations; (iii) temperature. After the installation of two monitoring systems and the analysis of the data acquired along a period of sixty years, the first hypothesis seems to have found a definitive confirmation, though temperature variations and soil settlement certainly worsened the structural damage. Another interesting example of static monitoring concerned the Santa Maria del Quartiere hexagonal dome in Parma, whose structural behaviour was investigated in order to define future interventions or different measures [8] [10]. The three mentioned buildings are perhaps the objects of the most significant and complex monitoring programs realised on historical monuments, not only for the huge number of sensors installed but also for the exceptional duration of measurement period [6].

As stated before, monitoring is a desirable practice also to assess the performance of strengthening interventions on historical buildings [7] [8]. In fact, a structural health monitoring (SHM) system is able to evaluate the structural behaviour during all the phases of the interventions and allows to modify the design solutions during the strengthening procedure, according to the actual deformation behaviour observed through the monitoring system. This was, for instance, the case of the interventions on Santa Maria Gloriosa dei Frari in Venice [7].

The static monitoring systems installed in the "Regina Montis Regalis" monumental complex combines most of the features recalled in the above mentioned cases. In fact, such monitoring concerns the evolution of a cracked state due to a progressive foundation settlements in a daring structure. Furthermore, the system has been installed in order to monitor the stability of the dome and the structural performance of an important strengthening intervention.

In the past years analyses were occasionally performed on static and dynamic monitoring data acquired on the "Regina Montis Regalis" Basilica, as documented in [11] [12] [13]. This article reports a systematic analysis of the data acquired from 2004 to 2014 by the monitoring instruments installed on the Basilica. Special attention was focused on the trends extracted from the periodic measuments performed by the crackmeters, the extensometers along the main axes of dome and the load cells placed at the ends of the tie-bars. 


\section{BASILICA OF "REGINA MONTIS REGALIS"}

The "Regina Montis Regalis" Basilica is a monument of great historical, architectural and structural significance, owing its fame primarily to the great masonry oval dome. With internal axes 37.23 by $24.89 \mathrm{~m}$, the dome is one of the largest in the world (after the Pantheon and Saint Peter in Rome, S. Maria del Fiore in Florence and Gol Gumbaz Mausoleum in India). The geometry of the dome was conceived by Francesco Gallo, who supervised to its construction in the years 1672-1750 $[11]$.

\section{Figure 1 about here}

The oval drum-dome system is supported by eight huge masonry pillars stiffened by the walls separating the chapels in their lower portion. A slender and transparent drum connects the dome to the underlying structures. The dome has a thickness varying from $2.20 \mathrm{~m}$ at the impost to $1.27 \mathrm{~m}$ at the top. It is reinforced by eight ribs on the extrados, radially connected to the eight buttresses. Four of these buttresses, adjacent to the major axis of the oval, are hollow. The dome is topped by a huge heavy sandstone lantern and is surrounded by a tiburio. Eight oval windows are located, between the buttresses, in this region of the dome and tiburio. The space between the tiburio and the vault is filled, up to a variable level, with light-weight materials, while full masonry sections at the buttress locations ensure structural continuity. The top of the tiburio is connected to the dome by reverse vault. From historical records and direct inspections, it has been ascertained that the dome was constructed in general by arranging the mortar bed joints along the parallels and slanting them according to the curvature of the meridians. However a detailed examination of the pattern on the extrados made it possible to identify two sets of relieving arches built in the thickness of the dome and the drum respectively above the oval openings in the dome and at an intermediate height between the triple windows of the drum and the dome impost. The openings of the oval windows are built by means of thick oval masonry rings, while the two rectangular lateral openings of the triple windows are surmounted by stone architraves. 


\subsection{Cracks pattern and strengthening systems}

The Basilica of Vicoforte is affected by a widespread system of cracks encompassing various zones of the structure. Despite this, the most significant cracks are located at the impost of the dome and in correspondence of the buttresses base (Figure 2-a).

The development of the cracks at the dome impost was facilitated by the triple windows of the drum and by the oval windows of the dome. Building a dome-drum system with large openings was driven by the need of reduce the foundation loading. Indeed, the excessive foundation loading and the nature of the foundation soil [14] caused in the previous construction phases differential settlements and the development of the first cracks. Currently, the 84 cracks at the dome impost add up to a total width of 416 . They run in the sub-vertical meridian direction and in correspondence of the openings become thicker and propagate following the direction connecting the upper and the lower series of openings. The width of the main crack is $48 \mathrm{~mm}$. It is located on the west side of the Basilica and almost reaches the closing ring of the dome, as shown in Figure 2(b). The second region of interest, at the base of the buttresses, displays oblique cracks induced by the radial thrusting action of the dome. The wider and longer cracks are observed in the two hollow buttresses situated to the north and south side of the Basilica.

\section{Figure 2 about here}

Concerns over severe differential settlements and cracking phenomena prompted the decision to undertake inspection, monitoring and strengthening interventions. A strengthening measure to contrast the further development of the web cracks was put in place during the years 1985-1987. It consists of 56 tie-bars placed within holes drilled in the masonry at the top of the drum along 14 tangents around the perimeter at 4 different levels (see Figure 3 and Figure 4 ). The continuity of the strengthening system is obtained through an anchorage system appositively designed and depicted in Figure 4. The tie-bars slightly tensioned at $50 \mathrm{kN}$ by jacks were re-tensioned in 1997 to compensate the stress losses [12]. This strengthening system probably collaborates with the three iron circular rings embedded at the base of the dome during its construction in 1734 (see Figure 3b), whose integrity was checked by an Impact Echo Scanner survey [14]. The total cross section of 
the original strengthening system is about $8350 \mathrm{~mm}^{2}$ while that of the modern one is approximately $3215 \mathrm{~mm}^{2}$.

Figure 3 about here

Figure 4 about here

\subsection{Static monitoring system}

The static monitoring of the Basilica began in 1983 when the first instruments were installed to control the evolution of the significant crack patterns. In the following decades, the monitoring system underwent several upgrading. The last one occurred in 2004 when the acquisition procedure was automatized. The 133 instruments of the current static monitoring system can be subdivided in two groups: instruments for the measurement of strains, stresses and cracks and instruments for the measurement of the boundary conditions. The first group includes: 12 crackmeters to check the evolution of the web cracking of the Basilica; 20 horizontal pressure cells to determinate the stress in the dome and in the eight buttresses; 1 vertical pressure cell near the top of the dome above the main meridian crack to determinate the circumferential compression stress; 56 load cells installed at the end of each tie-bar to control its load condition; 2 orthogonal wire gauges at the impost of the dome along the main axes to assess the Basilica overall geometry, and 12 nails for additional manual measurements of convergence. The second group of instruments, instead, includes: 1 hygrometer, 25 temperature sensors, 3 piezometric electric cells and 1 hydrometer.

The layout of sensors whose data were analysed are reported in Figure 5 and

Figure 6. The instruments are marked with a contraction of the instrument type ("T" for thermometers, "CM" for crackmeters-LVDTs, "LC" for load cells, "E" for wire gauges) and with the instrument number. In detail, Figure 5(a) shows the position of the cell loads used to monitoring the structural efficacy of the strengthening interventions whereas Figure 5 (d) depicts the two wire gauges located at the impost of the dome along the minor and major axes of the dome.

Figure 6(a) depicts the position of the working crackmeters. Precisely, 9 sensors are located in correspondence of the main cracks of the drum-dome system at about $32 \mathrm{~m}$ (from CM1 to CM9) and 1 crackmeter monitors the principal cracks of the dome (CM10). Similarly, 
Figure 6(b) concerns the temperature sensors, which are placed, respectively, inside the Basilica (red markers), outside the Basilica (blue markers), in the hole of the staircases (violet markers), on the tie-bars (orange markers) and on the extrados of the dome (green markers). The sensors at the extrados of the dome are located at about $50 \mathrm{~m}$ while all the other temperature sensors are approximatively at $32 \mathrm{~m}$.

Figure 5 about here

Figure 6 about here

\section{ANALYSIS OF THE STATIC MONITORING DATA}

The data acquired by the static monitoring system from November 2004 to November 2014 were analysed. The main aims of the analysis are check the damage state of the Basilica and verify the effectiveness of the tie-bars put in place in 1987. Monitored quantities such as crack openings, tension exerted by the tie-bars, or the overall dome dimensions measured by the extensometers, are affected by the temperature fluctuations. For instance, Figure 7 shows the evolving trend of the monitored phenomena overlaid with the seasonal trend due to temperature variations. As a consequence, the first step of data analysis consists in determining to what extent the structural behaviour of the dome-drum system, the effectiveness of the strengthening intervention and the evolution of damage are affected by seasonal temperature variations. The samples obtained by all the instruments do not allow to appreciate daily temperature variations while the annual periodicity is clearly visible in all the acquisitions.

\section{Figure 7 about here}

\subsection{Crack opening behaviour over the time}

\subsubsection{Seasonal behaviour of the crack opening}

The seasonal temperature variations imply opening/closing cycles of the cracks in the Basilica. In general, contrary to what attended [8] [15] [16], the cracks evidenced a maximum opening in 
summer and a closing process during the winter. As proof of this unexpected crack behavior Figure 8 depicts, for instance, the time histories of a crackmeter and of an internal thermometer. The figure clearly shows as the maximum temperature and crack opening take place in summer. This unexpected seasonal behavior of the cracks is probably related to the different efficacy of the strengthening system during the winter and the summer. Topic investigated in detail in a next section.

\section{Figure 8 about here}

The magnitude of the seasonal oscillations depends on the different temperature and restraint conditions of the monitored portions of masonry [3]. Consequently, the opening induced by fluctuations vary from one crack to another, being generally in the range 0.01-0.2 $\mathrm{mm}$.

\subsubsection{Time evolution of the crack opening}

The crack opening trend provides information on the presence of structural diseases of the building and on the effectiveness of past strengthening interventions. Indeed, cracks that show a constant evolution must be checked periodically to define the most efficient treatment avoiding to compromise irremediably the integrity of the structure.

The data recorded between 2004 and 2014 display a substantial stability of the cracks opening. In fact, despite some crack opening plots show the presence of a clear decreasing/increasing trend the annual trend of the phenomenon is so slow to be negligible. For instance Figure 9 (a) depicts the time-history of CM09 having the most important evolving trend. Nevertheless the annual trend of the phenomenon is approximately of $0.013 \mathrm{~mm} /$ year and therefore considerably lower than the ones observed for the cracks of other historical masonry dome, as show in Table 1 [2] [7] [8]. An anomalous behaviour was observed in corrispondence of CM02. Indeed, the visualization of the CM02 time-history shows a clear discontinuity at the beginning of the 2013, as show in Figure 9(b). After this date the opening of the crack doubled and the seasonal oscillation became 10 time bigger. In detail the opening moves from $6 \mathrm{~mm}$ to $11 \mathrm{~mm}$ and the amplitude of the oscillation from 0.04 $\mathrm{mm}$ to $0.4 \mathrm{~mm}$.

Figure 9 about here 
Table 1 about here

\subsection{Effectiveness of the strengthening interventions over time}

The data recorded by the cell-load sensors provide useful information on the time-dependent behaviour and efficiency of the tie-bars put in place in the years 1985-1987 and therefore on the structural effectiveness of the strengthening intervention. The data are analysed splitting the cellload sensors in four groups and considering the position and the level of the tie-bars. In detail, the LC4, LC8, LC12, LC16, LC20, LC24, LC28, LC32, LC36, LC40, LC44, LC48, LC52 measures the tension force of the first and upper ring; the LC3, LC7, LC11, LC15, LC19, LC23, LC27, LC31, LC35, LC39, LC43, LC47, LC51, LC55 the load of the second ring; the LC2, LC6, LC10, LC14, LC18, LC22, LC26, LC30, LC34, LC38, LC42, LC46, LC50, LC54 the force of the third ring and finally the LC1, LC5, LC9, LC13, LC17, LC21, LC25, LC29, LC33, LC37, LC41, LC45, LC49, LC53 the tension force of the fourth and lower ring.

\subsubsection{Seasonal behaviour of the load in the tie-bars}

The seasonal temperature variations imply a fluctuation of the tie-bars load. This behaviour is associated to the different thermal expansion coefficient and thermal inertia of masonry and steel, that imply a change of the anchorage condition of the tie-bars. The validity of the above stated relation for all the tie-bars can be easily proved comparing the temperature measured by the thermometers placed on the tie-bars with the cyclic behaviour of the data acquired by the cell-load sensors, as done, for instance, in Figure 10. The load in the tie-bar monitored by the LC6 is at its minimum in the summer months, therefore in this time of year the strengthening system is less effective. The lower effectiveness of the strengthening system during the summer probably implies the unexpected behaviour of the cracks that evidence their maximum opening in summer.

\section{Figure 10 about here}

The magnitude of these seasonal oscillations is approximately in the range of $5 \mathrm{kN}$ for all the load cells. Indeed temperature records measured on tie-bars belonging to different levels, or having different positions, are more or less the same as shown for instance in Figure 11. 
Figure 11 about here

\subsubsection{Time evolution of the load in the tie-bars}

The bars were slightly tensioned at $50 \mathrm{kN}$ in 1987 to avoid the further development of the crack of the Basilica. In 1997 the strengthening system was re-tensioned to compensate the significant stress losses occurred over the decade. The tension force, which had dropped down to about $40 \mathrm{kN}$, was restored to the initial value [1]. From the re-tensioning no information is available before the 2004 when the static monitoring system was automated. The values of the tie-bars load on January $1^{\text {st }}, 2005$ were those reported in Figure 12. At that date, the tension force showed to vary considerably between tie-bars. Differently from behaviours such those described in [1], the tie-bar loads measured by the Basilica's monitoring system were even higher than $50 \mathrm{kN}$.

\section{Figure 12 about here}

In the following years the force exerted by the hooping, measured on a daily basis, varied with the annual trend reported in Figure 13, assuming on January 1st, 2014 the value in Figure 14.

\section{Figure 13 about here}

\section{Figure 14 about here}

Figure 13 and Figure 14 suggest the presence of important annual trends in correspondence of LC05 and LC44. The visualisation of the LC05 time-history, reported in Figure15(a), shows a discontinuity at the beginning of the 2013. In detail, the load dropped approximately of $20 \mathrm{kN}$ assuming the value of about $30 \mathrm{kN}$ after 2013. A similar discontinuity was not observed in the other tie-bars having the same position and belonging to the lower level. In these latter cases the load is seen to decrease over time but without appreciable singularities at the beginning of the 2013, as inferred for instance from Figure15(b) for sensor LC06. It is worth noticing that the tie-bar LC05 is in correspondence of the crack CM02 that in the same year doubled its opening. 
The simple plot of the data acquired by the cell-load sensors evidences some local anomalies in the loads applied by the tie-bars. Indeed, as shown in Figure 16, in some specific cases the load trends measured over time do not follow a monotonic behaviour. As a consequence, the behaviours observed for the tie-bars on the East side of the Basilica will require supplementary investigations and analyses.

\section{Figure 16 about here}

\subsection{Trends in measured deformation and stress}

The overall dimension of the dome was monitored by two extensometers located at the impost of the dome and along the two main axes of the dome. Figure 17 reports the data acquired by the two extensometers. The oscillatory component is to be entirely ascribed to the seasonal behaviour of the Basilica, independently from the seasonal cycles of the wire. In fact, the direct effect of the changes in temperature was removed using to two wires having different coefficients of thermal expansions. The overall geometry of the dome seems to increase in summer and decrease in winter. This seasonal behaviour is clearly visible in Figure 17, where also the evolving trends are reported. Based on the trends it can be argued that over the decade 2004-2014 the overall dimension of the dome has slightly increased. However this finding will require further investigations, in order exclude instrumental drifts.

\section{Figure 17 about here}

Finally, the data acquired by the pressure cells do not present clear trends. Thus, any consideration about stresses in the Basilica must be done with care, possibly relying on multiphysics models.

\section{CONCLUSIONS}

The data acquired by the static monitoring system of the "Regina Montis Regalis" Basilica evidence the evolving trends of some monitored phenomena. In more details, the analysis of the 
data recorded in the decade 2004-2014, together with available historical data, proves that: (i) the damage state of the Basilica is generally stable in the investigated period, especially when compared with literature reports on similar structures. The absence of important trends in the crack opening reflects also the effectiveness of the strengthening intervention put in place in 1987. The crack width variations are small and essentially ascribable to temperature variations. An exception is represented by the crack located in correspondence of the buttresses at $32 \mathrm{~m}$ height, whose opening doubled at the beginning of the 2013; (ii) although the effectiveness of the hooping system varies due to the seasonal temperature cycles, no significant differences in its efficacy can be appreciated over the examined decade. Indeed, the force applied by the tie-bars presents a slightly decreasing trend. An exception among this behaviour is represented by a tie-bar in the South-West portion of the drum-dome system, monitored by LC05 sensor. The load of that element, which is placed on the same side as the crackmeter CM02, at the beginning of the 2013 dropped down to $30 \mathrm{kN}$ from the initial value of about $48 \mathrm{kN}$ in 2004 . It is also worth noting that this tie-bar is not the only one with a measured load significantly lower than the initial tension, equal to $50 \mathrm{kN}$. The behaviours observed for the tie-bars, especially those on the East side of the Basilica, will require supplementary investigations and additional measurements. At the end of the analyses, specific measures, including re-tensioning of the tie-bars, will be evaluated.

\section{REFERENCE}

[1] I. Lombillo, H. Blanco, J. Pereda, L. Villegas, C. Carrasco and J. Balbás, "Structural health monitoring of a damaged church: design of an integrated platform of electronic instrumentation, data acquisition and client/server software," Structural Control and Health Monitoring, vol. 23, no. 1, pp. 69-81, 2016.

[2] F. Marazzi, P. Tagliabue and F. M. Corbani, "Traditional vs innovative structural health monitoring of monumental structures: A case study," Structural Control and Health Monitoring, vol. 18, no. 4, pp. 430-449, 2011.

[3] G. Bartoli, A. Chiarugi and V. Gusella, "Monitoring systems on historic buildings: the Brunelleschi dome," Journal of Structural Engineering, vol. 122, no. 6, pp. 663-673, 1996.

[4] B. Bertaccini, "Santa Maria del Fiore Dome Behavior: Statistical Models for Monitoring Stability," International Journal of Architectural Heritage, vol. 9, no. 1, pp. 25-37, 2015.

[5] M. Fanelli, "Importance of Monitoring, Behavior Analysis, and Diagnostic Techniques for Preservation of Great Historical Structures," International Journal of Architectural Heritage, vol. 9, no. 1, pp. 2-6, 2015.

[6] F. Ottoni and C. Blasi, "Results of a 60-Year Monitoring System for Santa Maria del Fiore Dome in Florence," International Journal of Architectural Heritage, vol. 9, no. 1, pp. 7-24, 
2015.

[7] P. Rossi and C. Rossi, "Monitoring of two great venetian cathedrals: San Marco and Santa Maria Gloriosa dei Frari," International Journal of Architectural Heritage, vol. 9, no. 1, pp. 58-81, 2015.

[8] F. Ottoni, "Dome Strengthening By Encircling Ties: A Monitored Experiment," International Journal of Architectural Heritage, vol. 9, no. 1, pp. 82-95, 2015.

[9] E. Coïsson and C. Blasi, "Monitoring the French Panthéon: From Rondelet's Historical Surveys to the Modern Automatic System," International Journal of Architectural Heritage, vol. 9, no. 1, pp. 48-57, 2015.

[10] F. Ottoni, "From geometrical and crack survey to static analysis method: the case study of Santa Maria del Quartiere dome in Parma (Italy)," in Proceedings of SAHC 2008, 2008.

[11] M. A. Chiorino, A. Spadafora, C. Calderini and S. Lagomarsino, "Modeling strategies for the world's largest elliptical dome at Vicoforte," International Journal of Architectural Heritage, vol. 2, no. 3, pp. 274-303, 2008.

[12] M. A. Chiorino, C. Calderini, A. Spadafora and R. Spadavecchia, "Structural assessment, testing, rehabilitation and monitoring strategies for the world's largest elliptical dome and sanctuary at Vicoforte," in RILEM Symposium on On Site Assessment of Concrete, Masonry and Timber Structures-SACoMaTiS 2008, 2008.

[13] M. A. Chiorino, R. Ceravolo, A. Spadafor, L. Zanotti Fragonara and G. Abbiati, "Dynamic characterization of complex masonry structures: the Sanctuary of Vicoforte," International Journal of Architectural Heritage, vol. 5, no. 3, pp. 296-314, 2011.

[14] T. Aoki, T. Komiyama, Y. Tanigawa, S. Hatanaka, N. Yuasa, H. Hamasaki and R. Roccati, "Non-destructive testing of the Sanctuary of Vicoforte," in In Proceedings of 13th international brick and block masonry conference, Amsterdam, 2004.

[15] A. Chiarugi, M. Fanelli and G. Giuseppetti, "Analysis of a Brunelleschi-type dome including thermal loads," in IABSE Symposium on Strenghtening of Building Structure, Diagnosis and Therapy, Zurich, 1983.

[16] C. Blasi, "Elaborazione ed interpretazione di dati sperimentali da sistemi di monitoraggio: la cattedrale di Santa Maria del Fiore," Raccolta monografica, Dipartimento di Ingegneria Civile-Sezione Struttura, no. 13, 1990. 

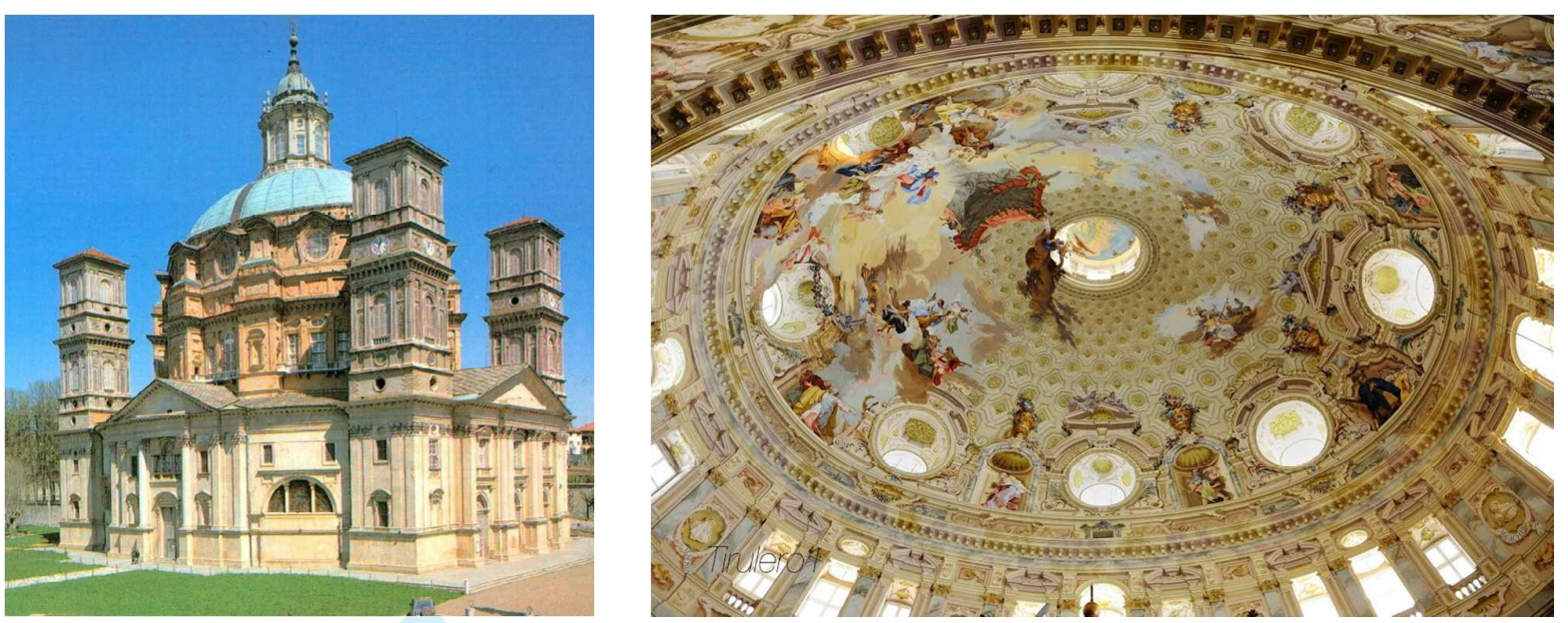

Figure 1. External and internal view of the Basilica of "Regina Montis Regalis". 


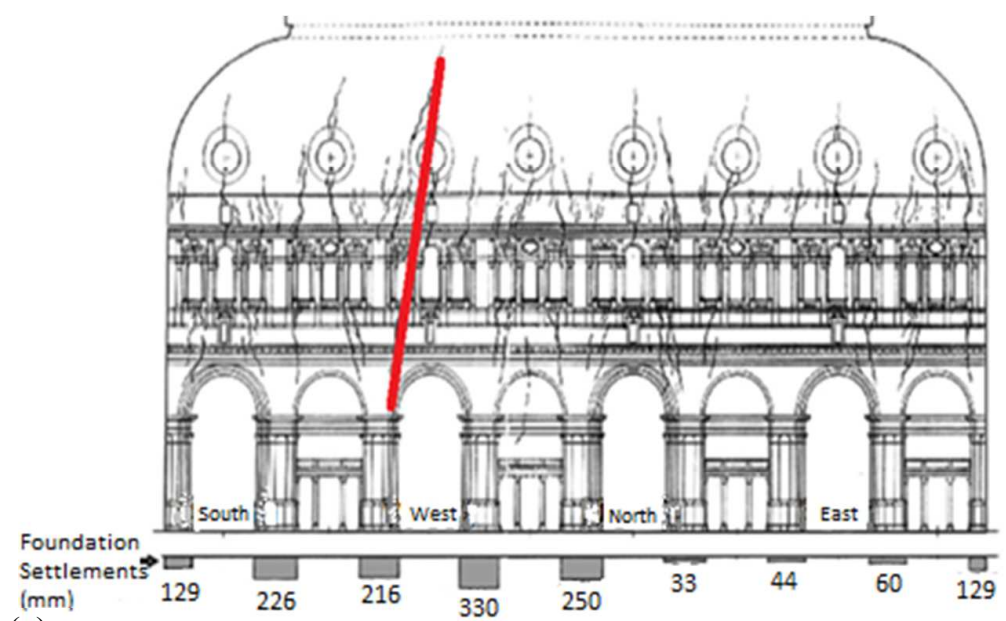

(a) (b)

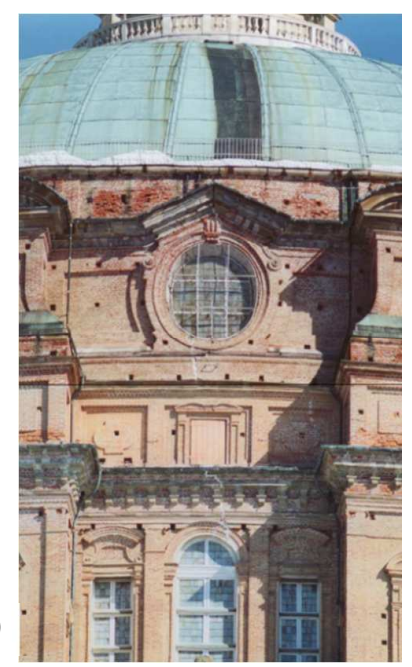

Figure 2. (a) Cracking pattern and foundation settlements; (b) main crack on the west side of the Basilica. 


1
2
3
4
5
6
7
8
9
10
11
12
13
14
15
16
17
18
19
20
21
22
23
24
25
26
27
28
29
30
31
32
33
34
35
36
37
38
39
40
41
42
43
44
45
46
47
48
49
50
51
52
53
54
55
56
57
58
59
60

(a)

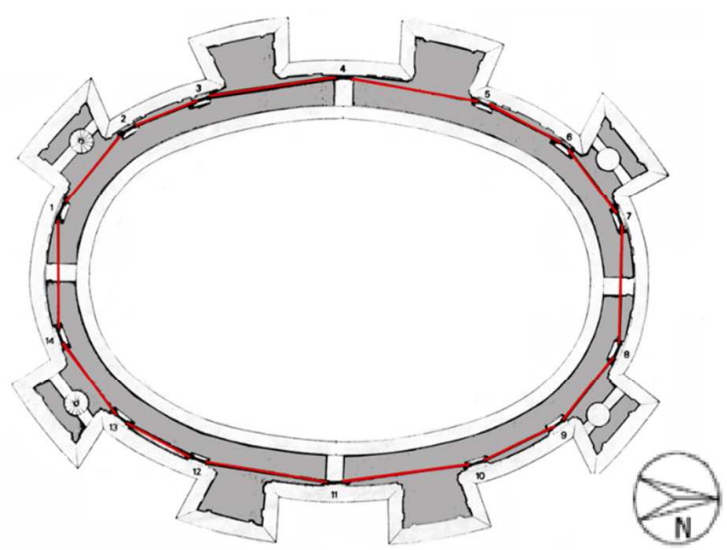

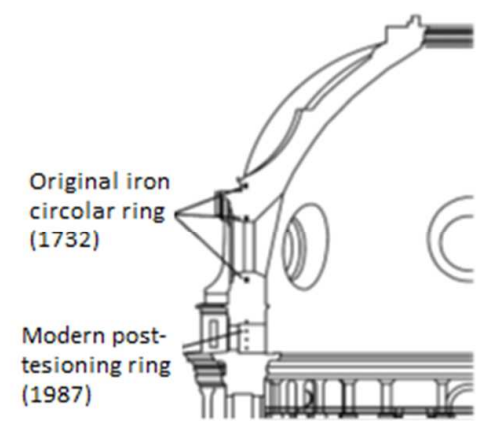

(b)

Figure 3. (a) Plan of the strengthening system realised in 1987 and (b) modern and original strengthening systems. 


1
2
3
4
5
6
7
8
9
10
11
12
13
14
15
16
17
18
19
20
21
22
23
24
25
26
27
28
29
30
31
32
33
34
35
36
37
38
39
40
41
42
43
44
45
46
47
48
49
50
51
52
53
54
55
56
50

(a)

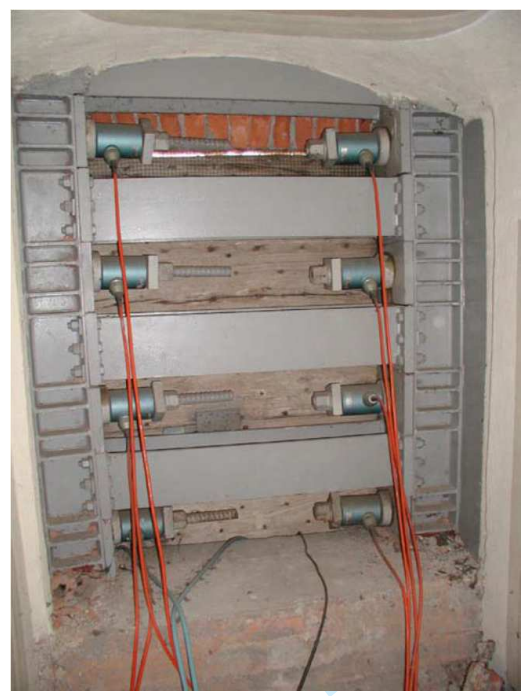

(b)

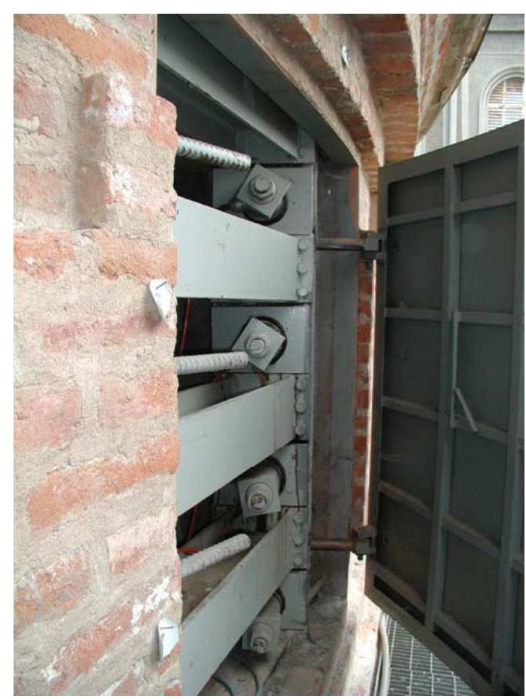

Figure 4. (a) Tie-bar ends equipped with load cells and (b) tie-bars end with the anchorage system. 

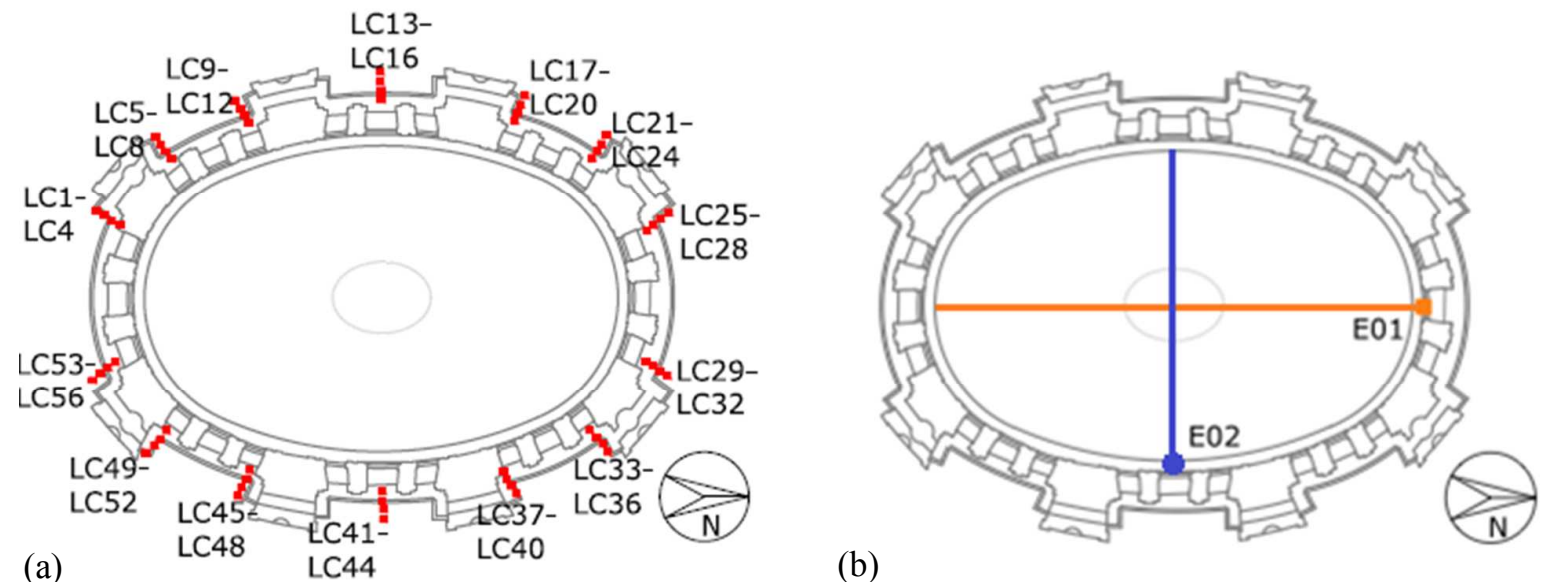

Figure 5. Schematic illustration of the location of (a) load cells and (b) wire gauges. 


1
2
3
4
5
6
7
8
9
10
11
12
13
14
15
16
17
18
19
20
21
22
23
24
25
26
27
28
29
30
31
32
33
34
35
36
37
38
39
40
41
52
59
50
40
50
45
48
49
50
51
53

(a)
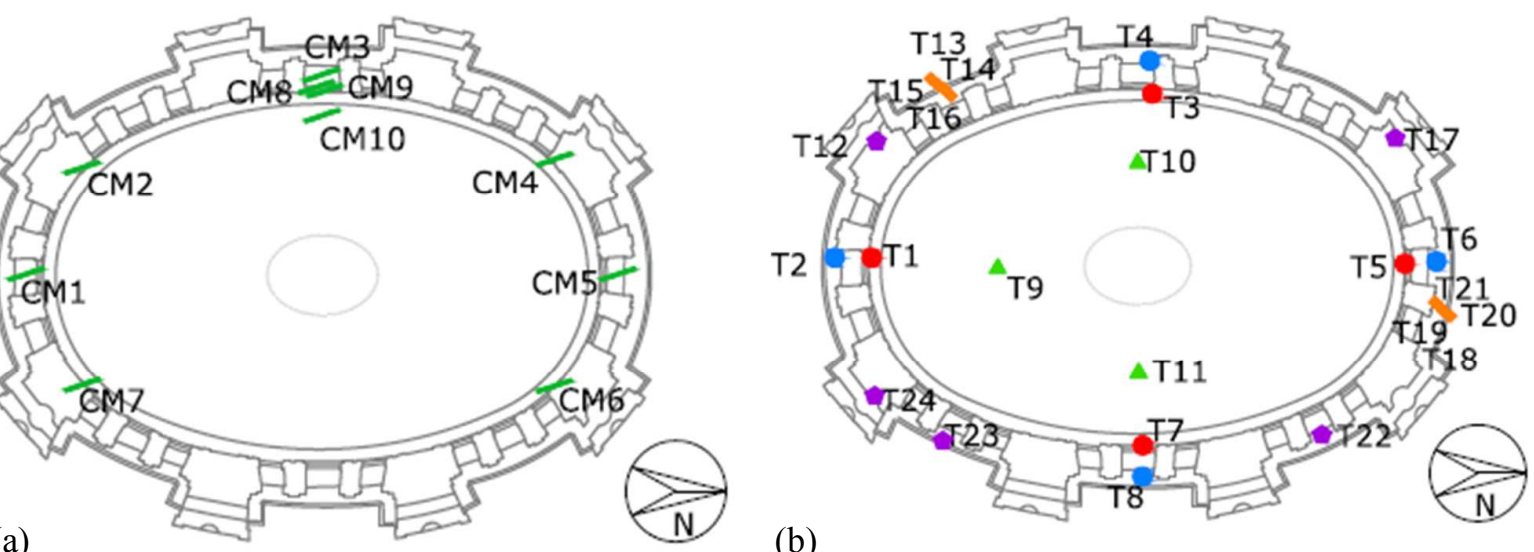

(b)

Figure 6. Schematic illustration of the location of (a) crackmeters and (b) temperature sensors. 

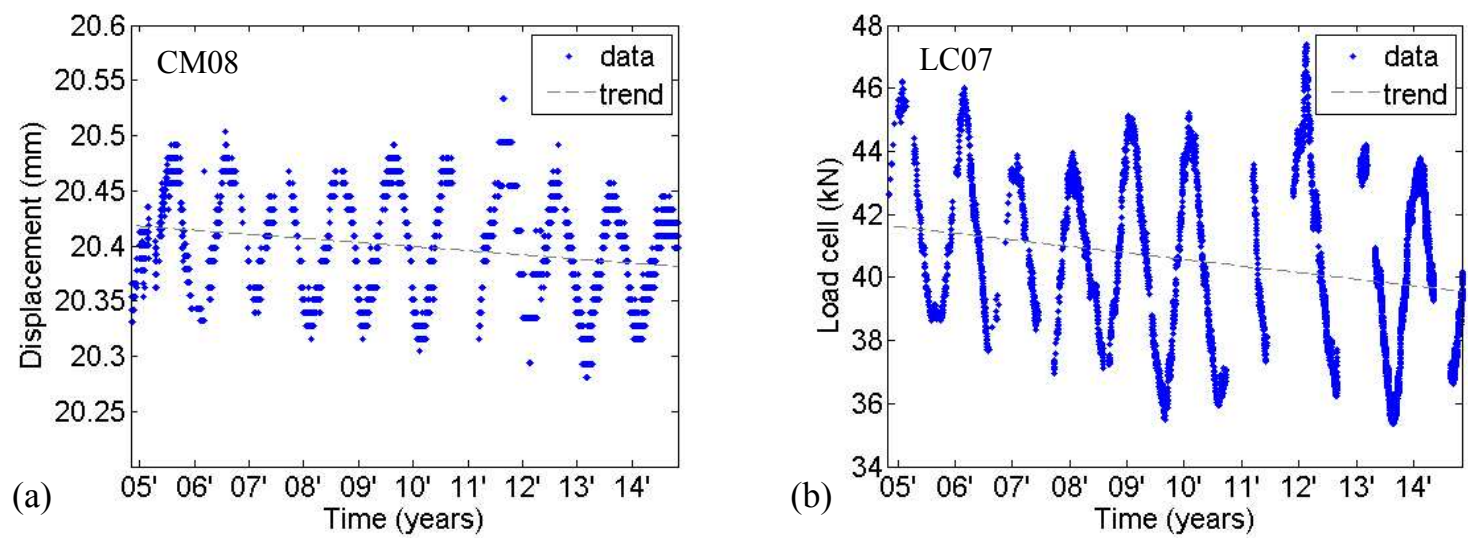

Figure 7. Data acquired by (a) crackmeter CM08 and by (b) load cell LC07. 

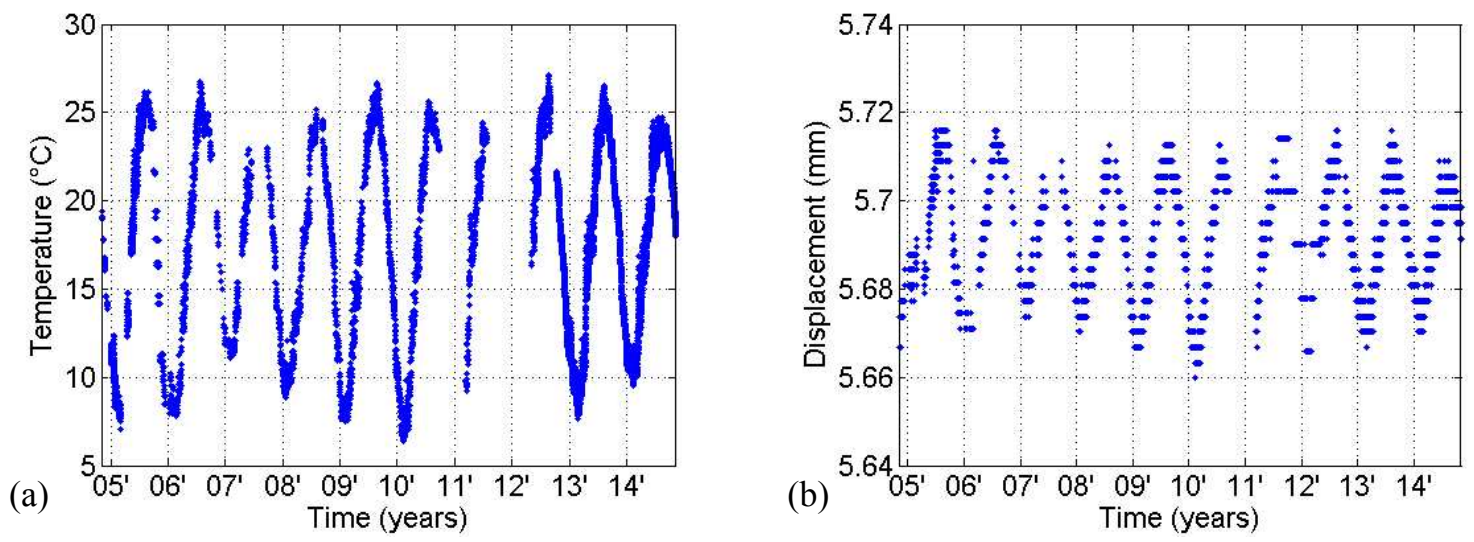

Figure 8 . Data acquired by (a) thermometer T03 and by (b) crackmeter CM03. 

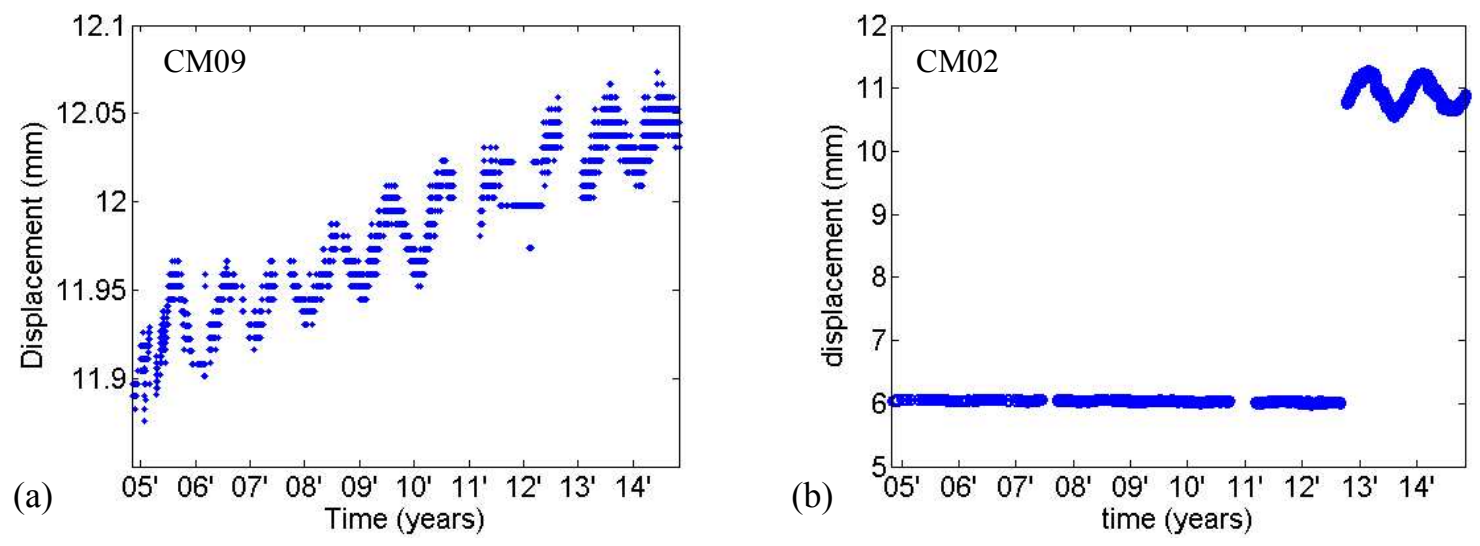

Figure 9. Crack opening measured by (a) crackmeter CM09 and (b) crackmeter CM02. 
1

2

3

4

5

6

7

8

9

10

11

12

13

14

15

16

17

18

19

20

21

22

23

24

25

26

27

28

29

30

31

32

33

34

35

36

37

38

39

40

41

42

43

44

45

46

47

48

49

50

51

52

53

54

55

56

57

58

59

60

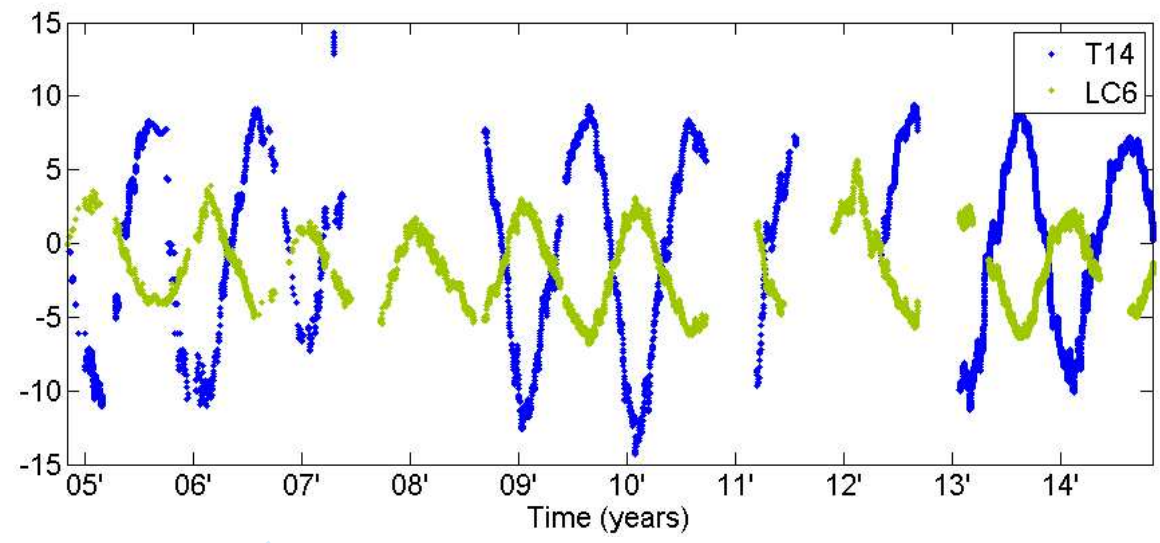

Figure 10. Overlaps of the time-history of data recorded by thermometer T14 and load cell LC6. 

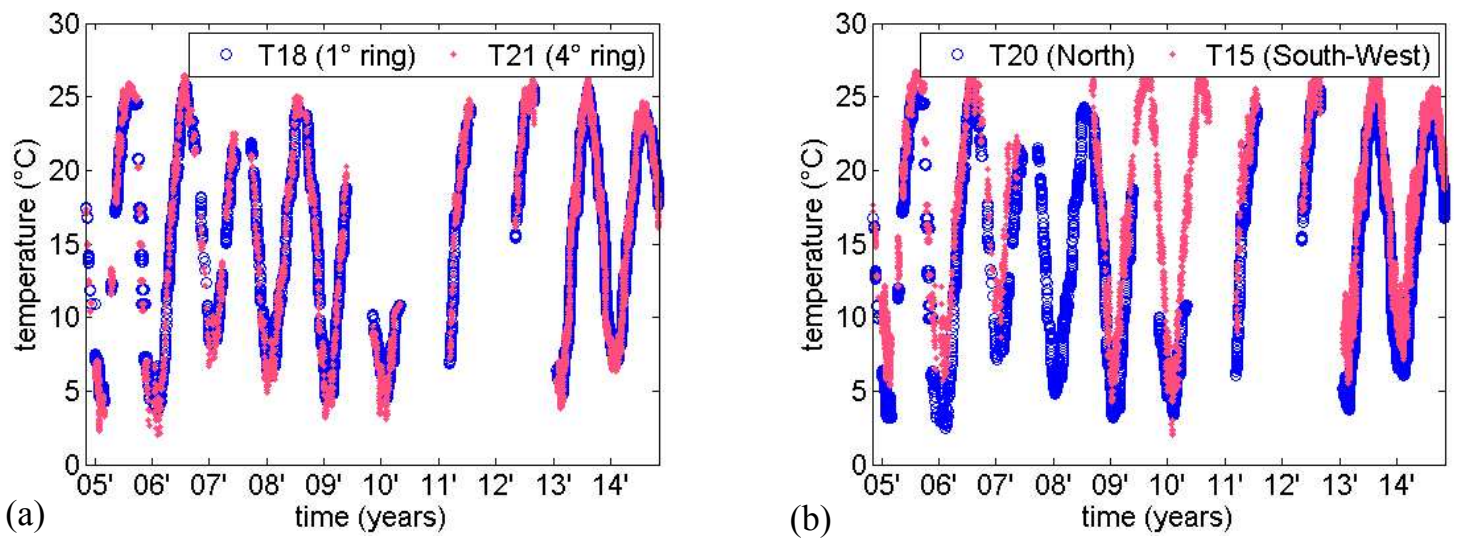

Figure 11. Temperature acquired on the tie-bars, respectively: (a) tie-bars belonging to different levels and having the same position and (b) tie-bars belonging to the same level and having different positions. 
1

2

3

4

5

6

7

8

9

10

11

12

13

14

15

16

17

18

19

20

21

22

23

24

25

26

27

28

29

30

31

32

33

34

35

36

37

38

39

40

41

42

43

44

45

46

47

48

49

50

51

52

53

54

55

56

57

58

59

60

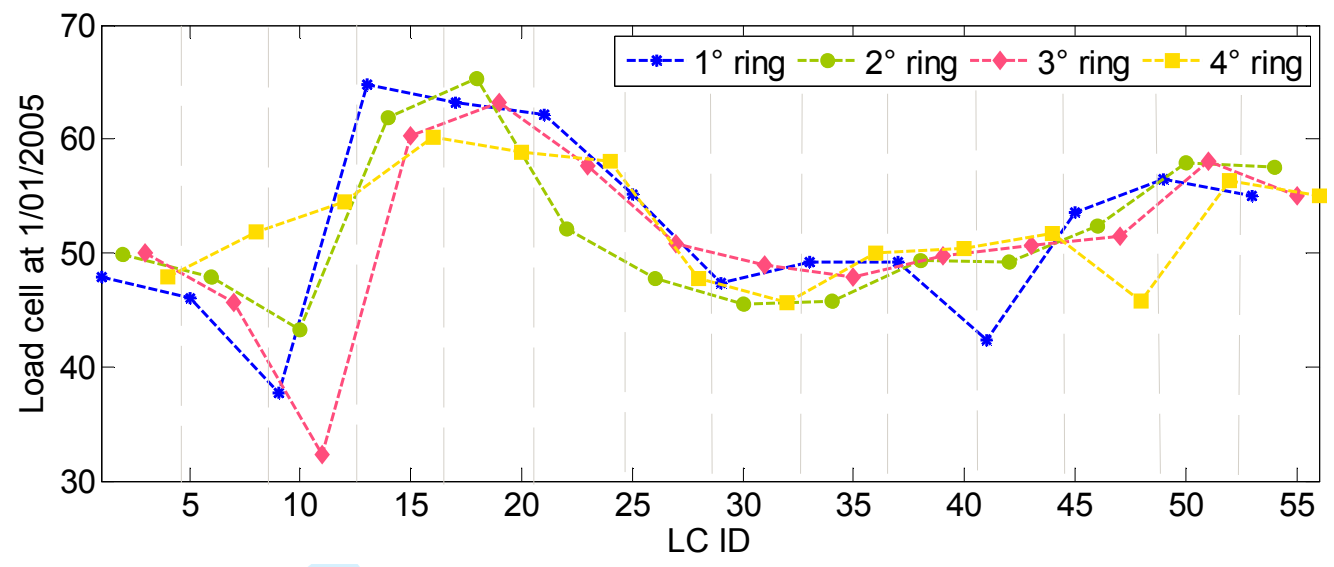

Figure 12. Force measured on the tie-bars on January, $1^{\text {st }}, 2005$. 


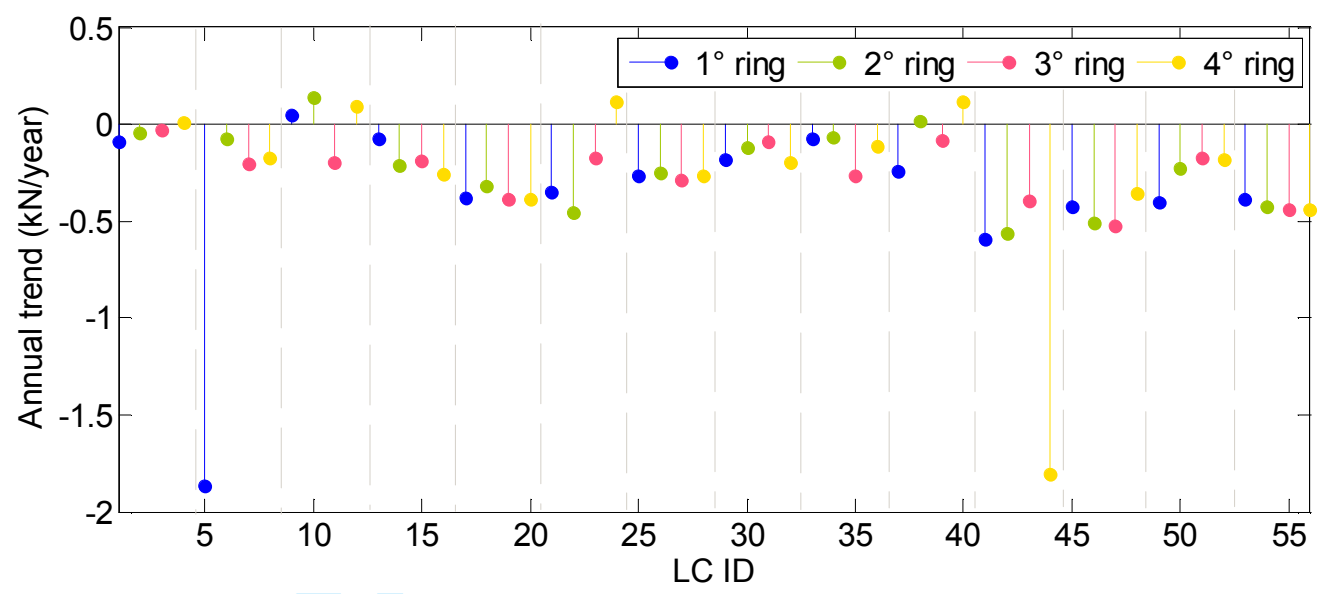

Figure 13. Annual trend of the tension load in different tie bars. 
1

2

3

4

5

6

7

8

9

10

11

12

13

14

15

16

17

18

19

20

21

22

23

24

25

26

27

28

29

30

31

32

33

34

35

36

37

38

39

40

41

42

43

44

45

46

47

48

49

50

51

52

53

54

55

56

57

58

59

60

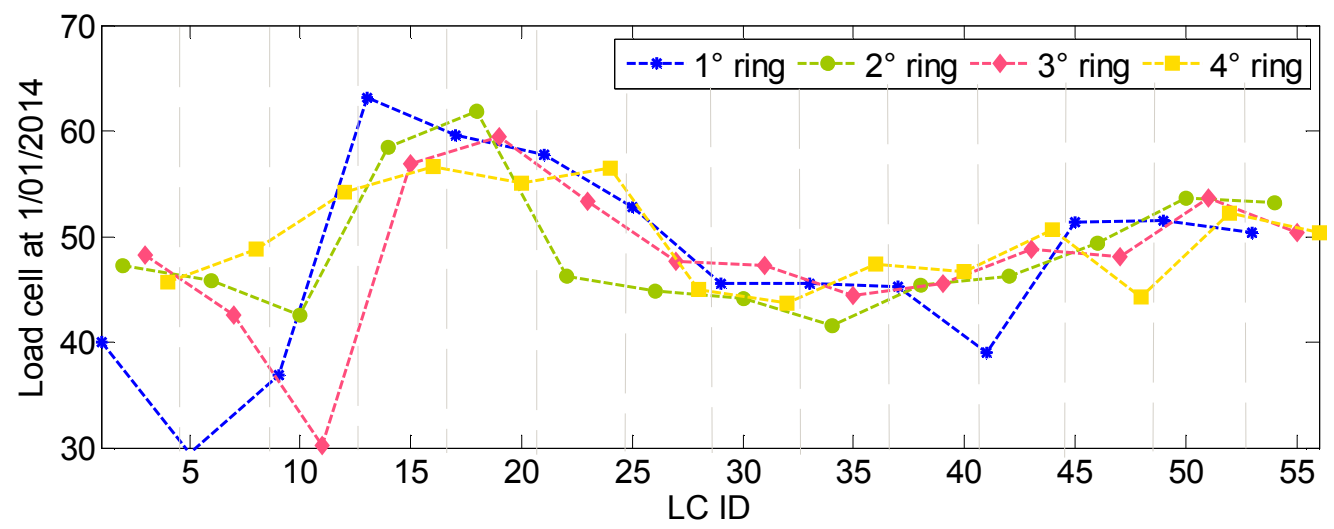

Figure 14. Force measured on the tie-bars on January, $1^{\text {st }}, 2014$. 

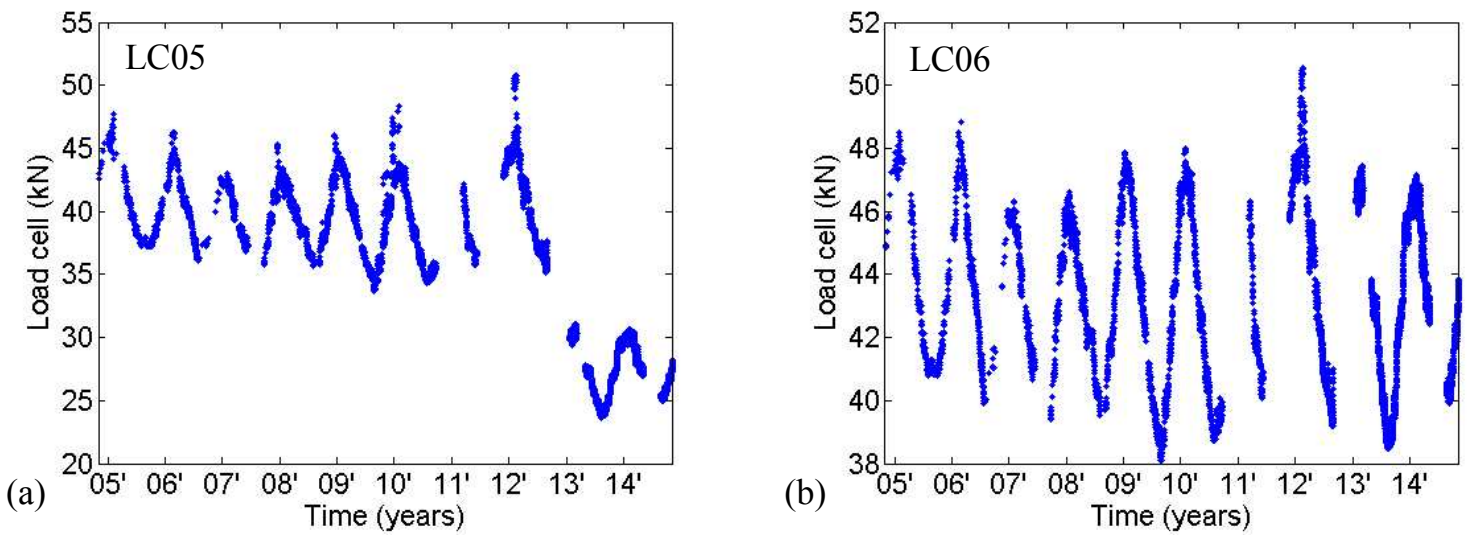

Figure 15. Time-histories of the load measured by (a) cell load LC05 and (b) cell load LC06. 

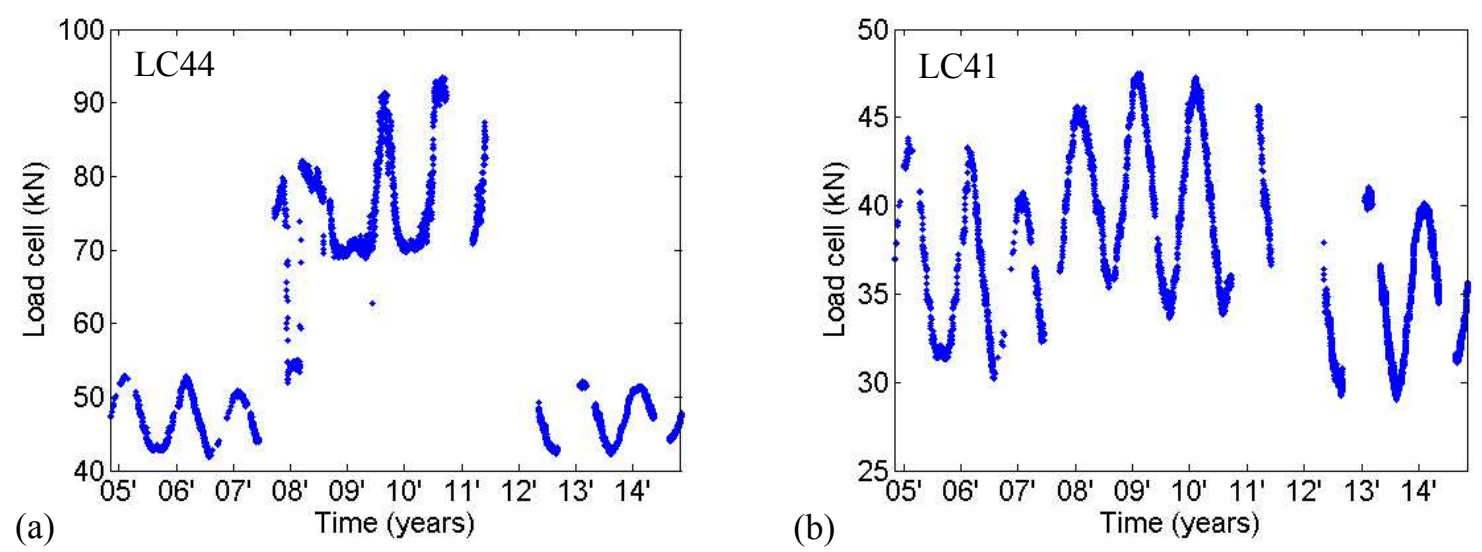

Figure 16. Time-histories of the load measured by (a) cell load LC44 and (b) cell load LC41. 

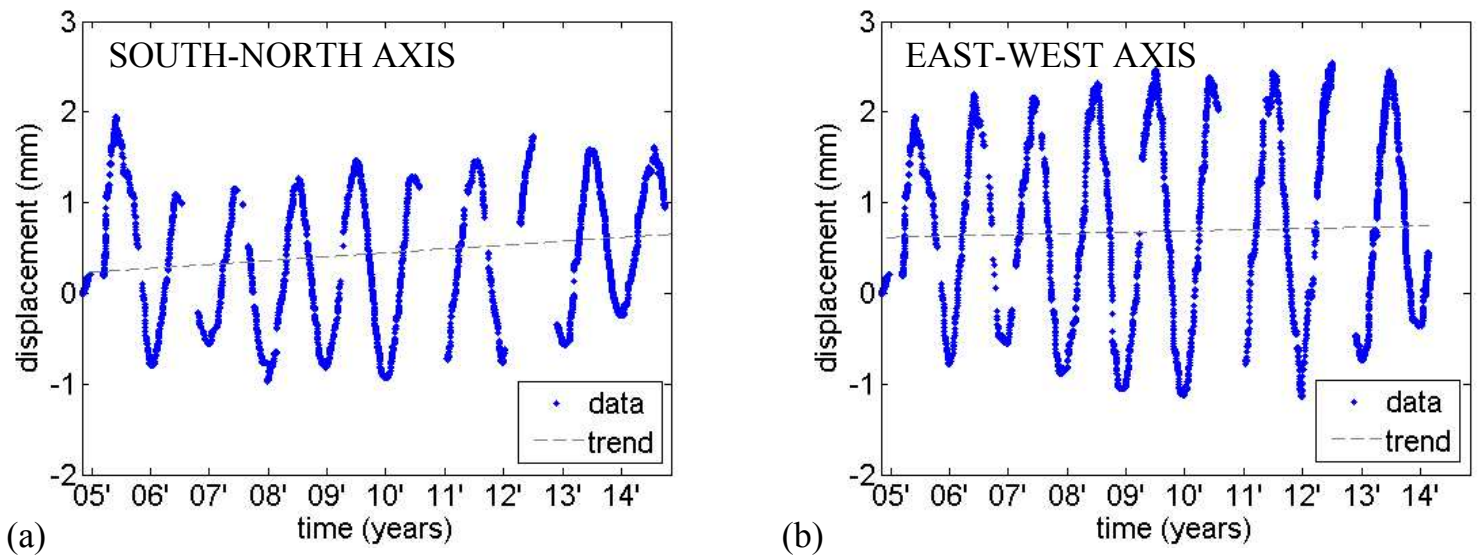

Figure 17. Extensometer time-histories: (a) South-North (major) axis (E01) and (b) East-West (minor) axis (E02). 


\begin{tabular}{ccccc}
\hline \hline & $\begin{array}{c}\text { Regina Montis } \\
\text { Regalis }\end{array}$ & $\begin{array}{c}\text { Santa Maria } \\
\text { del Quartiere }\end{array}$ & $\begin{array}{c}\text { Basilica di } \\
\text { San Marco }\end{array}$ & $\begin{array}{c}\text { Santa Maria } \\
\text { del Fiore }\end{array}$ \\
\hline Geometry & $\begin{array}{c}\text { Oval dome, main axes } \\
37.23 \mathrm{~m} \text { and } 24.89 \mathrm{~m}\end{array}$ & $\begin{array}{c}\text { Hexagonal dome, } \\
\text { inscribing circle } 20 \mathrm{~m}\end{array}$ & $\begin{array}{c}\text { Circular dome, } \\
\text { diameter } 12.5 \mathrm{~m}\end{array}$ & $\begin{array}{c}\text { Octagonal dome, } \\
\text { inscribing circle } 42 \mathrm{~m}\end{array}$ \\
\hline Annual trend & $0.013 \mathrm{~mm} /$ year & $0.8 \mathrm{~mm} /$ year & $0.42 \mathrm{~mm} / \mathrm{year}$ & $0.08 \mathrm{~mm} /$ year \\
\hline \hline
\end{tabular}

Table 1. Comparison between the maximum annual trend of monitored cracks in Regina Montis Regalis dome and literature data available for some historical domes. 
2017-02-03

\section{Monitoring of masonry historical constructions: 10 years of static monitoring of the world's largest oval dome}

\section{Ceravolo, Rosario}

Monitoring of masonry historical constructions: 10 years of static monitoring of the world's largest oval dome

Ceravolo R, De Marinis A, Pecorelli ML, Zanotti Fragonara L. Monitoring of masonry historical constructions: 10 years of static monitoring of the world's largest oval dome, Structural Control and Health Monitoring, Vol. 24, Issue 10, October 2017, Article number e1988 http://dx.doi.org/10.1002/stc. 1988

Downloaded from Cranfield Library Services E-Repository 